\title{
Influence of Splenectomy on the Biodistribution of Technetium-99m Dimercaptosuccinic Acid (99mTc-DMSA) in Rats
}

\author{
Maria Kadja Meneses Torres Açucena ${ }^{1 *}$, Kércia Regina Santos Gomes Pereira ${ }^{1}$, Arthur \\ Villarim Neto ${ }^{1}$, Amália Cínthia Meneses Rêgo ${ }^{1}$, Mario Bernardo-Filho ${ }^{2}$, Ítalo Medeiros \\ Azevedo $^{3}$, Irami Araújo Filho ${ }^{3}$, Aldo Cunha Medeiros ${ }^{3}$ \\ ${ }^{I}$ Centro de Ciências da Saúde; Universidade Federal do Rio Grande do Norte; Natal - RN - Brasil. ${ }^{2}$ Departamento \\ de Biofísica e Biometria; Instituto de Biologia Roberto Alcantara Gomes; Universidade do Estado do Rio de \\ Janeiro; Av. 28 de Setembro, 87; 20551030; Rio de Janeiro - RJ - Brasil. ${ }^{3}$ Departamento de Cirurgia; \\ Universidade Federal do Rio Grande do Norte; Av. Nilo Peçanha, s/n; aldo@ufrnet.br; 59012300; Natal - RN - \\ Brasil
}

\begin{abstract}
This study aimed to evaluate if the splenectomy alters the biodistribution of 99mTc-DMSA and renal function in Wistar rats. The animals were separated in the groups: splenectomy $(n=6)$ and control $(n=6)$. After splenectomy (15 days), the administration of $0.1 \mathrm{ml}$ of $99 \mathrm{mTc}-\mathrm{DMSA} I V(0.48 \mathrm{MBq}$ ) was carried out. Thirty minutes later, kidney, heart, lung, thyroid, stomach, bladder and femur and samples of blood were isolated. The organs were weighed, counted and the percentage of radioactivity $/ g$ (\%ATI $/ g)$ determined. Serum urea and creatinine, hematocrit, leukocytes and platelets were measured. Statistics by t test $(p<0.05)$ was done. There was a significant reduction in $\% A T I / g$ in kidney and blood ( $p<0.05)$ of splenectomized animals, a significant increase $(p<0.05)$ of urea $(88.8 \pm$ $18.6 \mathrm{mg} / \mathrm{dL})$ and creatinine $(0.56 \pm 0.08 \mathrm{mg} / \mathrm{dL})$, compared to the controls $(51.5 \pm 1.6,0.37 \pm 0.02 \mathrm{mg} / \mathrm{dL}$, respectively), as well as increase in platelets and leucocytes, and hematocrit reduction. The analysis of the results indicates that in rats, splenectomy seems to alter the renal function and the uptake of $99 \mathrm{mTc}$-DMSA.
\end{abstract}

Keywords: Splenectomy, Biodistribution, Technetium, Rats

\section{INTRODUCTION}

The spleen has a complex physiologic role, as evidenced by its multiple immunologic, filtration, reservoir, and hematopoietic functions. It is more efficient in removing non-opsonized bacteria, mostly encapsulated organisms, than is the liver. It is the main site of the opsonins, tuftsin and properdin, as well as of immunoglobulin-M antibody synthesis (Brendolan et al., 2007). Splenectomy has been indicated for trauma, tumor and hematological disorders (Petroianu, 2005). In some splenectomized patients severe infection and disseminated intravascular coagulation (DIC) with post-mortem congestion in every organ as well as bleeding may occur. Frequent causes of death are progressive renal failure, pneumococcal sepsis, DIC, hemorrhage, pulmonary and renal congestion (Tajiri et al., 2007).

Technetium-99m-dimercaptosuccinic acid (99mTc-DMSA) scintigraphy is the standard method used to evaluate permanent renal damage in children with urinary tract infection (Stokland et al., 2007; Piepsz et al., 1999). The use of 99mTcDMSA for renal cortical scintigraphy, introduced in the 1970s, has been shown to be sensitive and 
specific for diagnosing pyelonephritis in children (Majd and Rushton, 1992). Quantitative singlephoton emission computed tomography (SPECT) measurement of $99 \mathrm{mTc}-\mathrm{DMSA}$ uptake by the kidneys is a reproducible method that can reliably be used to monitor serial changes in individual renal function. The method provides information concerning the percentage injected dose per cubic centimeter of renal tissue and functional kidney volumes, and can obtain individual kidney uptake, which provides a practical index for evaluating individual renal function (Groshar et al., 1997). The renal uptake of $99 \mathrm{mTc}-\mathrm{DMSA}$ is dependent on renal blood flow and proximal tubular cell membrane transport function (Taylor, 1982, Saha, 2004).

When a radiopharmaceutical is administered to a patient, the process of biodistribution begins; this consists of absorption, distribution, metabolism and excretion. The biodistribution of radiopharmaceuticals can be changed by surgical procedures performed in animal models (AraújoFilho et al., 2007; Chacon et al., 2007). The biodistribution of radiopharmaceuticals is based on the same pharmacokinetic principles described for therapeutic agents. So, when a patient is using a given drug, or was previously submitted to a surgical procedure, the biodistribution of a radiopharmaceutical injected intravenously to perform scintigraphy might change.

In spite of the evidence of renal complications in the postoperative of splenectomy, this problem has been scarcely studied. The present study aimed at investigating whether splenectomy could change the biodistribution of $99 \mathrm{mTc}-\mathrm{DMSA}$ in some organs of rats and could affect the red blood cells, white blood cell and platelet count and the urea and creatinine concentrations.

\section{MATERIAL AND METHODS}

Male Wistar rats, weighing $295 \pm 31 \mathrm{~g}$, were supplied by the Center of Experimental Surgery of the Federal University of Rio Grande do Norte, Brazil. The animals were housed under standard conditions, and fed rodent chow and water ad libitum. The protocol for this study was approved by the Institutional Animal Care Committee, and all surgical procedures and care administered to the animals were in accordance with Brazilian College of Animal Experimentation guidelines.
After 7 days of acclimatization in the laboratory, the rats were randomly allocated to two groups of 6 rats each. The groups were denominated splenectomy (SP) and control (C).

After overnight fast, the rats were anesthetized with intraperitoneal thiobarbital $(20 \mathrm{mg} / \mathrm{kg}$ weight $)$ and ketamine $(50 \mathrm{mg} / \mathrm{kg}$ weight) intra-muscular (IM). A midline laparotomy was performed after the skin was shaved and sterilized with $70 \%$ ethanol. The spleens of SP group rats were removed. The laparotomy wound was closed with 4-0 nylon in layers and individual rats were placed in separate cages. They were allowed water $a d$ libitum and rat chow after $24 \mathrm{~h}$ postoperatively. The $\mathrm{C}$ rats $(\mathrm{n}=6)$ were neither anesthetized nor operated on. Hydration was performed with normal $0.9 \% \mathrm{NaCl}$ solution (saline) injected subcutaneously in the back of the rats for the first two postoperative days. Postoperative pain was treated with tenoxicam (Roche Pharm., Brazil); 10 $\mathrm{mg} / \mathrm{kg}$ was given IM to the rats once a day for the first three days. Body weight was monitored weekly throughout the entire 15-day experimental period. Activity, mucosa and skin color were observed daily.

On the 15th day all the animals were anesthetized again, and injected with $0.1 \mathrm{~mL}$ of $99 \mathrm{mTc}-\mathrm{DMSA}$ $(0.66 \mathrm{MBq})$ in the orbital plexus. After $30 \mathrm{~min}$, blood was collected by cardiac puncture for dosages and the animals were killed by a lethal dose of anesthetic. Kidney, heart, lung, thyroid, stomach, bladder and femur were isolated and samples of blood were separated. The organs were washed in saline, weighed on a balance (Bel-Mark 160-II Itália $\left.{ }^{\circledR}\right)$ and the radioactivity counted using a 1470 Wizard $^{\mathrm{TM}}$ Gamma Counter - Perkin-Elmer, Finland, with automatic correction of radiation decay. The percentage of radioactivity/g (\%ATI/g) of each organ was calculated by dividing the activity per gram of the sample tissues by the total activity administered to each animal.

Serum urea and creatinine were measured with a Konelab 60i Spectrophotometer (assay kit from Weiner, São Paulo, Brazil). Hematological analysis of hematocrit (HCT), white blood cells (WBC) and platelets was performed using an Abbot Cell Dyn 3500 Automatic Analyzer, São Paulo, Brazil. The data were expressed as mean \pm standard deviation (SD). Group comparison was made using ANOVA and the post-hoc Student test, with a significance level set at $p<0.05$. 


\section{RESULTS}

Table 1 shows significant decrease of radioactivity (Tc-99m-DMSA) in the kidney and on blood uptake in animals submitted to splenectomy than those found in control rats $(\mathrm{p}<0.05)$. The radioactive uptake predominated in the kidney and in bone (femur). Specifically, the lung had higher uptake in splenectomized rats than in controls $(\mathrm{p}=0.008)$. In the other organs (heart, thyroid, stomach, bladder and femur) we did not detect significant differences in $99 \mathrm{mTc}$-DMSA uptake between splenectomized and control rats ( $>0.05)$. Postsplenectomy symptoms such as hematuria, pale mucosa and lethargy were observed in 6 animals, but not in control rats. We observed no significant body weight loss in splenectomized rats, compared to controls.

Table 1 - Results of 99mTc-DMSA biodistribution in rats (splenectomy and control).

\begin{tabular}{lccc}
\hline \multirow{2}{*}{ Organs } & \multicolumn{2}{c}{ \%ATI/g } & \multirow{2}{*}{ P } \\
\cline { 2 - 3 } & Splenectomy & Control & 0.041 \\
Kidney & $2.10 \pm 0.30$ & $3.27 \pm 0.81$ & 0.066 \\
Heart & $0.13 \pm 0.04$ & $0.12 \pm 0.02$ & 0.008 \\
Lung & $0.23 \pm 0.05$ & $0.12 \pm 0.06$ & 0.357 \\
Thyroid & $0.07 \pm 0.02$ & $0.06 \pm 0.02$ & 0.225 \\
Stomach & $0.08 \pm 0.02$ & $0.06 \pm 0.02$ & 0.736 \\
Bladder & $0.34 \pm 0.43$ & $0.42 \pm 0.35$ & 0.924 \\
Fêmur & $2.04 \pm 0.01$ & $1.93 \pm 0.01$ & 0.012 \\
Blood & $0.30 \pm 0.09$ & $0.53 \pm 0.16$ & \\
\hline
\end{tabular}

Mean \pm Standard deviation; \%ATI/g, percent of radioactivity per gram.

To examine the effects of prior splenectomy on kidney injury, we assessed the levels of urea and creatinine (Table 2). In splenectomized rats, urea and creatinine values $(88.3 \pm 18.5 \mathrm{mg} / \mathrm{dL}$ and 0.56 $\pm 0.08 \mathrm{mg} / \mathrm{dL}$ respectively) were significantly $(\mathrm{p}<0.05)$ higher than in controls $(51.7 \pm 1.3 \mathrm{mg} / \mathrm{dL}$ and $0.37 \pm 0.02 \mathrm{mg} / \mathrm{dL}$ respectively). Changes in platelet and WBC counts are summarized in Table
2. At postoperative day 15 , the number of platelets and WBC were significantly higher in splenectomized rats than in controls $(\mathrm{p}<0.05)$. Hematocrit was significantly lower in splenectomized rats $(22.8 \pm 4.7 \%)$ than in controls (46.8 $\pm 9.02 \% ; \mathrm{p}=0.0002)$.

Table 2 - Values of urea, creatinine, platelets, hematocrit (HCT) and white blood cell (WBC) in rats after splenectomy.

\begin{tabular}{cccc}
\hline Dosages & Splenectomy & Control & p \\
\hline Urea $(\mathrm{mg} / \mathrm{dL})$ & $88.3 \pm 18.5$ & $51.7 \pm 1.3$ & 0.01 \\
Creatinine $(\mathrm{mg} / \mathrm{dL})$ & $0.56 \pm 0.08$ & $0.37 \pm 0.02$ & 0.0014 \\
Platelets $(\mathrm{k} / \mu \mathrm{L})$ & $1252 \pm 248$ & $530 \pm 251$ & 0.002 \\
HCT $(\%)$ & $22.8 \pm 4.7$ & $46.8 \pm 9.02$ & 0.0002 \\
WBC $(\mathrm{k} / \mu \mathrm{L})$ & $15.2 \pm 2.9$ & $3.3 \pm 0.8$ & $<0.001$ \\
\hline
\end{tabular}

Mean \pm standard deviation; WBC, white blood cells; $p$-value from $t$ test for independent samples; HCT, hematocrit. 


\section{DISCUSSION}

During the last years, non operative management has become the primary method of preserving the spleen. Splenectomy is required for around $50 \%$ of splenic trauma injuries (Velmahos et al., 2000). The white blood cell count (WBC) is an integral part of sepsis diagnosis. Early WBC trends alert the physician about the possibility of sepsis and allow prompt therapeutic response. However, postsplenectomy diagnosis of sepsis based on elevated WBC is not suitable due to the fact that leukocytosis is a physiologic response to splenectomy, similar to the phenomenon of elevated postsplenectomy platelet count (Bessler et al., 2004). Some reports suggest that postsplenectomy $\mathrm{WBC}$ in patients with sepsis is greater and more persistent than the WBC in patients without sepsis (Rutherford et al., 1994).

In our study, we tried to verify if splenectomy was able to alter the biodistribution of $99 \mathrm{mTc}$-DMSA to some organs, especially to the kidneys, the preferential uptake target of this radiopharmaceutical. As all animals had hematuria, leukocytosis and a significant platelet increase, we suspect that the splenectomized animals were affected by sepsis associated with disseminated intravascular coagulation. Increased white blood cell count and platelets are frequently the only hematological abnormalities observed in splenectomized patients (Petroianu et al., 2006). The phenomenon of temporary leukocytosis following splenectomy has been well known for many decades as a physiologic response to removal of the spleen. Leukocytosis is also a prominent finding of postoperative sepsis, a common and much feared complication of splenectomy. Therefore, confusion exists as to whether postsplenectomy leukocytosis should be considered a normal finding or a warning sign mandating treatment (Horowitz et al., 1992). Associated with hematuria, the animals in this study had significant kidney function impairment, due to the increase in urea and serum creatinine. These findings may explain the reduction in $99 \mathrm{mTc}-\mathrm{DMSA}$ uptake by renal parenchyma, reinforcing the characterization of postsplenectomy renal failure in rats.

Most authors encourage using DMSA scintigraphy for the early diagnosis of many diseases, because of its cost-effectiveness and safety. A focal reduction or absence of uptake in one or more areas of the kidney is considered abnormal, indicating renal damage. In positive cases, DMSA scintigraphy is found to be highly sensitive in detecting multiple lesions (Piepsz et al., 1999; Stogianni et al., 2007). Besides leukocytosis and renal impairment evidenced by changes in urea and creatinine, we observed that the splenectomized animals had intense anemia associated with low hematocrit in all operated rats. In fact, they all showed clear signs of pale mucosa and hematuria at the 15th postoperative day. Certainly these hematologic findings could be contributing to the renal failure and to the low uptake of the radiopharmaceutical in the blood of splenectomized animals.

In conclusion, the results suggest that splenectomy in rats results in important hematological changes as well as impairment in renal function and Tc99m-DMSA uptake.

\section{ACKNOWLEDEGMENT}

The authors thank Michael Germain, from Canada, for his help in revision of English language.

\section{RESUMO}

Estudo com objetivo de avaliar se a esplenectomia altera a biodistribuição do $99 \mathrm{mTc}$-DMSA e alguns parâmetros bioquímicos e hematológicos em ratos Wistar. Os animais forma divididos em 2 grupos: esplenectomizados $(n=6)$ e controle $(n=6)$. Após 15 dias, administração de $0,1 \mathrm{ml}$ de $99 \mathrm{mTc}$-DMSA via plexo orbital $(0,48 \mathrm{MBq})$ foi realizada. Rim, coração, pulmão, tireóide, estômago, bexiga e fêmur e amostras de sangue foram separadas. Após pesagem e contagem da radioatividade foi determinado o percentual de radioatividade/g (\% $\mathrm{ATI} / \mathrm{g})$. Dosadas uréia e creatinina sérica, hematócrito, plaquetas e leucócitos. Estatística pelo teste $t$, significância 0,05 foi realizada. Foi observada redução significante no \%ATI/g no rim e sangue $(\mathrm{p}<0,05)$ dos animais esplenectomizados, aumento significante $(\mathrm{p}<0.05)$ da uréia $(88,8 \pm 18,6$ $\mathrm{mg} / \mathrm{dL})$ e creatinina $(0,56 \pm 0,08)$, comparado aos controles $\quad(51,5 \pm 1,6 ; \quad 0,37 \pm 0,02 \mathrm{mg} / \mathrm{dL}$, respectivamente) assim como aumento de leucócitos e plaquetas e redução de hematócrito. Conclui-se que em ratos, a esplenectomia alterou a captação de $99 \mathrm{mTc}$-DMSA pelo rim, e a função renal. 


\section{REFERENCES}

Araújo-Filho, I.; Rego A. C. M.; Brandão-Neto J.; Villarim-Neto A.; Egito E. S. T.; Azevedo I. M.; Medeiros A. C. (2007), Biodistribution of the Radiopharmaceutical Sodium Pertechnetate after Biliopancreatic Bypass with a Duodenal Switch. Bra Arch Biol Technol., 50, 189-197.

Bessler, H.; Bergman, M.; Salman, H.; Beilin, B.; Djaldetti, M. (2004), The relationship between partial splenectomy and peripheral leukocyte count. $J$. Surg. Res., 122, 49-53.

Brendolan, A.; Rosado, M.M.; Carsetti, R.; Selleri, L.; Dear, T.N. (2007), Development and function of the mammalian spleen. Bioessays, 29,166-177.

Chacon, D.A.; Araújo-Filho, I.; Villarim-Neto,A.; Rêgo,A.C.; Azevedo, I.M.; Bernardo-Filho, M.; Brandão-Neto, J.; Medeiros, A.C. (2007), Biodistribution of the radiophamarceutical sodium pertechnetate (Na99mTcO4) after massive small bowel resection in rats. Acta Cir Bras., 22, 430-435.

Groshar, D.; Moskovitz, B.; Issaq, E.; Nativ, 0. (1997), Quantitative spect of DMSA uptake by the kidneys: assessment of reproducibility. Kidney Int., 52, 817820.

Horowitz, J.; Leonard, D.; Smith, J.; Brotman, S. (1992), Postsplenectomy leukocytosis: physiologic or an indicator of infection? Am Surg., 58,387-390.

Majd, M.; Rushton, H.G. (1992), Renal cortical scintigraphy in the diagnosis of acute pyelonephritis. Semin Nucl Med., 22, 98-111.

Petroianu, A.; Petroianu, L.P. (2005), Splenic autotransplantation for treatment of portal hypertension. Can J Surg., 48, 382-386.

Petroianu, A.; Resende, V.; Da Silva, R.G. (2006), Late follow-up of patients submitted to subtotal splenectomy. Int J Surg., 4, 172-178.
Piepsz, A.; Blaufox, M, D.; Gordon, I. (1999), Consensus on renal cortical scintigraphy in children with urinary tract infection. Semin Nucl Méd., 29, 160-174.

Rutherford, E.J.; Morris, J.A. Jr.; van Aalst, J.; Hall, K.S.; Reed, G.W.; Koestner, J.A. (1994), The white blood cell response to splenectomy and bacteraemia Injury, 25, 289-292.

Stogianni, A.; Nikolopoulos, P.; Oikonomou, I.; Gatzola, M.; Balaris, V.; Farmakiotis, D.; Dimitriadis, A. (2007), Childhood acute pyelonephritis: comparison of power Doppler sonography and Tc9m-DMSA scintigraphy. Pediatr Radiol., 37, 685690.

Stokland, E.; Jodal, U.; Sixt, R. (2007), Uncomplicated duplex kidney and DMSA scintigraphy in children with urinary tract infection. Pediatr Radiol., 37, 826828.

Tajiri, T.; Tate, G.; Enosawa, T.; Akita, H.; Ohike, N.; Masunaga, A.; Kunimura, T.; Mitsuya, T.; Morohoshi, T. (2007), Clinicopathological findings in fulminant-type pneumococcal infection: report of three autopsy cases. Pathol Int., 57, 606-612.

Taylor, A. (1982), Quantitation of renal function with static imaging agents. Semin Nucl Med., 12, 330-344.

Velmahos, G.C.; Chan, L.S.; Kamel, E. (2000), Nonoperative management of splenic injuries. Arch Surg., 135, 674-681.
Received: August 10, 2008; Revised: September 05, 2008; Accepted: September 08, 2008. 